\title{
Cegah Resistensi Kuman Dengan Pengkaderan Kelompok Peduli Antibiotika Rasional
}

\author{
Inayati *1, Yoni Astuti 2, dan Lilis Suryani 3 \\ Bagian Mikrobiologi, Fakultas Kedokteran dan Ilmu Kesehatan, Universitas Muhammadiyah Yogyakarta, Jl. Brawijaya, Taman Tirto, Kasihan \\ Bantul Yogyakarta \\ 2 Bagian Biokimia, Fakultas Kedokteran dan Ilmu Kesehatan, Universitas Muhammadiyah Yogyakarta, Jl. Brawijaya, Taman Tirto, Kasihan \\ Bantul Yogyakarta \\ 3 Bagian Mikrobiologi, Fakultas Kedokteran dan Ilmu Kesehatan, Universitas Muhammadiyah Yogyakarta, Jl. Brawijaya, Taman Tirto, \\ Kasihan Bantul Yogyakarta \\ Email: inayati@umy.ac.id \\ DOI: $10.18196 / \mathrm{ppm} .36 .311$
}

\begin{abstract}
Abstrak
Infeksi menjadi masalah kesehatan masyarakat penting terutama di negara berkembang dan membutuhkan antibiotika untuk pengobatan. Tahun 2010 kematian penyakit infeksi di Indonesia 31,2\%. Intensitas penggunaan antibiotik yang relatif tinggi berakibat resistensi bakteri terhadap antibiotik dan mempengaruhi morbiditas, mortalitas, ekonomi dan sosial. Hasil penelitian Antimicrobial Resistant in Indonesia , 43\% Escherichia coli resisten berbagai antibiotik. Edukasi dan informasi penggunaan antibiotika rasional diperlukan masyarakat untuk menghindari pengunaan antibiotika tidak rasional. Pengabdian masyarakat dilakukan di Desa Ambarketawang, Gamping, Sleman, daerah perkotaan di mana ketersediaan antibiotika cukup mudah diperoleh masyarakat dan kemungkinan ditemukan penggunaaan antibiotik secara tidak rasional dan belum mengetahui akibatnya. Sosialisasi penggunaan antibiotika rasional dan bahaya penggunaan antibiotika tidak rasional diikuti aktif 56 peserta, melakukan focus group discussion menggali persepsi penggunaan antibiotika rasional diikuti 2 kelompok terdiri 16 orang/kelompok dipandu 2 fasilitator dan 2 transkriptor. Pelatihan pemantauan penggunaan antibiotika rasional dilakukan oleh 3 kelompok yang melakukan survei terhadap 5 - 7 Kepala Keluarga di desa Ambarketawang Gamping Sleman. Rencana tindak lanjut adalah penyusunan Panduan Kerja Kelompok Peduli Penggunaan Antibiotika dan luaran berupa Buku Panduan Penggunaan Antibiotika.
\end{abstract}

Kata Kunci: Antibiotika Rasional, Resistensi Kuman, Kelompok Peduli

\section{Pendahuluan}

Infeksi menjadi masalah kesehatan masyarakat terutama di negara berkembang dan membutuhkan antibiotika untuk pengobatan. Infeksi menyebabkan kematian 4 juta orang, di mana 27\% di Asia Tenggara (WHO, 2004). Tahun 2010 kematian di Indonesia 31,2\%. Antibiotik tersedia tanpa resep, digunakan tidak tepat dosis, indikasi, interval pemberian dan lama pemakaian (Brad S, M.D, 2013). Terdapat 50 juta resep antibiotik tidak diperlukan dari 150 juta resep setiap tahun di Amerika Serikat (Akalin, 2002).

Di Indonesia $92 \%$ masyarakat tidak menggunakan antibiotik (Sistiagustin M., 2012). Terdapat 40 - 62\% antibiotik digunakan untuk penyakit yang tidak memerlukan antibiotik. Beberapa Rumah Sakit ditemukan 30\% - 80\% tanpa indikasi (Hadi,2008). Pemahaman masyarakat yang salah antibiotika dikonsumsi tidak tuntas dan pengawasan penjualan antibiotik buruk, masyarakat bebas membeli antibiotik tanpa informasi penggunaannya (Sistiagustin M., 2012). Intensitas penggunaan antibiotik yang relatif tinggi berakibat resistensi bakteri terhadap antibiotik dan memengaruhi morbiditas, mortalitas, ekonomi, dan sosial.

Resistensi berawal di Rumah Sakit, selanjutnya berkembang di masyarakat, khususnya S. pneumoniae, S.aureus, dan E.coli, dimana 43\% E. coli resisten berbagai antibiotik (AMRIN Study, 2005). Resistensi antimikroba terjadi karena selection pressure akibat penggunaan 
antimikroba, dapat dihambat dengan penggunaan antibiotika bijak, dan karena penyebaran mikroba resisten, dihambat dengan pengendalian infeksi secara optimal. (Permenkes, 2015)

Edukasi penggunaan antibiotika tepat dan pencegahan infeksi penting untuk menghindari penggunaan antibiotika tidak tepat (WHO, 2001). Penyuluhan dengan bertatap muka secara langsung lebih efektif dibandingkan dengan tindakan penyuluhan melalui media massa atau selebaran. Hasil penelitian pengetahuan responden yang baik sebelum penyuluhan 9,3\% meningkat menjadi $40 \%$ (Chalvy W. dkk; 2013)

Prediksi peningkatan penggunaan antibiotika tidak rasional di Yogyakarta khususnya di Ambarketawang, Gamping, Sleman terkait tingkat pengetahuan masyarakat yang rendah, memerlukan dukungan masyarakat dan kader kesehatan. Peningkatan pengetahuan dan peran masyarakat dan kader kesehatan tentang penggunaan antibiotika yang rasional sangat penting tujuan pengabdian masyarakat adalah meningkatkan pemahaman khalayak sasaran tentang penggunaan antibiotika yang rasional dan resistensi kuman sebagai akibat penggunaan antibiotika yang tidak rasional serta meningkatkan peran masyarakat dan kader kesehatan dalam rasionalitas penggunaan antibiotika dengan pembentukan Kelompok Peduli Penggunaan Antibiotika Rasional dan tersedianya Panduan Program Kerja Kelompok Peduli Penggunaan Antibiotika di Ambarketawang.

\section{Metode Pelaksanaan}

Responden sebanyak 15 orang kader posyandu dan PKK desa Ambarketawang, Gamping, Sleman, DI. Yogyakarta dengan kriteria usia 40 - 60 tahun dan berpengalaman sebagai kader selama 10 sd 15 tahun. Metode pelaksanaan pengabdian masyarakat meliputi tahapan kegiatan sebagai berikut.

1. Sosialisasi tentang antibiotika dan penggunaannya secara rasional.

2. Sosialisasi tentang resistensi kuman sebagai akibat penggunaan antibiotika tidak rasional.

3. Focus Group Discussion kepada kelompok masyarakat untuk menggali persepsi tentang penggunaan antibiotika yang rasional.

4. Latihan pemantauan penggunaan antibiotika yang terjadi.

5. Melakukan evaluasi, analisis, dan mendiskusikan hasil uji coba pemantauan penggunaan antibiotika.

6. Menyusun panduan program kerja kelompok peduli penggunaan antibiotika rasional.

Bahan dan alat yang digunakan adalah leaflet tentang himbauan penggunaan antibiotika secara rasional untuk mencegah resistensi kuman sebagai media ajar untuk menambah pengetahuan masyarakat. Kisi-kisi FGD sebagai panduan pelaksanaannya dan form ceklist survei penggunaan antibiotika rasional. Data hasil FGD berupa resume 2 kelompok FGD sedangkan hasil survei penggunaan antibiotika di desa Ambarketawang didapatkan data 3 kelompok surveiyor meliputi $17 \mathrm{KK}$ di desa Ambarketawang. Data yang didapatkan dianalisa secara deskriptif dan disajikan dalam bentuk tabel

Hasil dan Pembahasan

Sosialisasi tentang penggunaan antibiotika rasional dan resistensi kuman bertujuan meningkatkan pemahaman khalayak sasaran mengenai penggunaan antibiotika yang rasional 
dan resistensi kuman sebagai akibat penggunaan antibiotika tidak rasional. Sosialisasi dilaksananakan pada hari Senin, 17 April 2017 dengan peserta sebanyak 56 orang. Pelaksanaan kegiatan tersebut dapat dilihat pada gambar-gambar di bawah ini dan Daftar Hadir peserta sosialisasi (Gambar 1 sd Gambar 2)

Adapun Materi sosialisasi sebagai tertera pada leaflet di bawah ini.
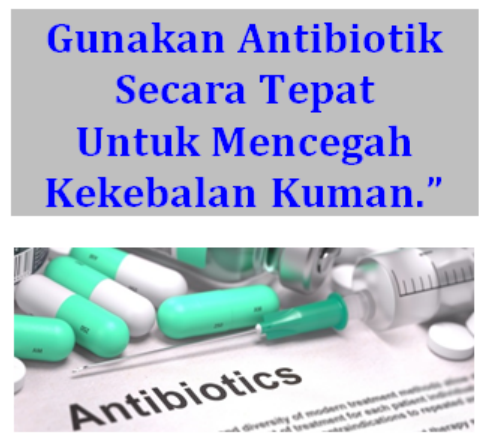

Antibiotika adalah obat untuk mencegah dan mengobati infeksi yang disebabkan oleh bakteri. Penggunaan AB yang tidak tepat ini ternyata dilakukan banyak pihak. Tidak hanya kalangan medis, pasien pun seringkali 'nakal', memaksa dokter meresepkan antibiotik walaupun tidak perlu.

Analisis Data Riskesdas 2013 mendapatkan $31 \%$ rumah tangga menyimpan $\mathrm{AB}$ dan $69 \% \mathrm{AB}$ sebagai obat sisa. Bahkan, AB juga kerap digunakan peternak dan petani sebagai insektisida tanaman, campuran pakan ternak ayam, sapi, kambing, ikan, udang dan sebagainya
Penggunaan antibiotik secara sembarangan, termasuk membeli di toko obat tanpa resep, berpotensi memicu resistensi/kebal yaitu Antibiotik menjadi tidak dapat membunuh bakteri. Jika itu terjadi, nantinya akan semakin banyak penyakit yang tak bisa disembuhkan dengan antibiotik.

Saat ini banyak kuman telah menjadi kebal terhadap antibiotik. Resistensi antibiotika mengakibatkan biaya kesehatan menjadi lebih tinggi karena penyakit lebih sulit diobati; butuhkan waktu perawatan yang lebih lama; dan membawa risiko kematian yang lebih besar

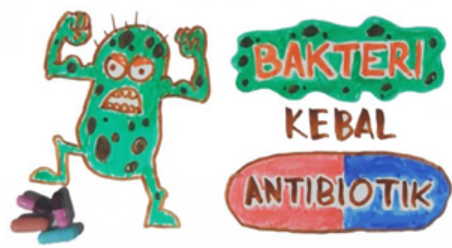

Berikut ini adalah cara bijak menggunakan antibiotik untuk menghambat kemungkinan terjadinya resistensi, seperti digariskan Kementerian Kesehatan RI.

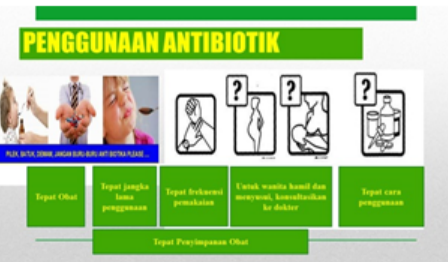

1. Gunakan antibiotik sesuai dengan resep dan jangka waktu yang ditentukan oleh dokter. Tebuslah antibiotik di apotek, sehingga kualitas atau mutunya lebih terjamin

2. Tanyakan kepada dokter jenis obat yang mengandung antibiotik. Bila sudah diberi tahu, biasanya ada keterangan "Habiskan" di bungkus obatnya, dan harus dihabiskan.

3. Penggunaan obat yang salah dapat menyebabkan antibiotik tidak efektif lagi, sehingga tidak dapat membunuh kuman (resistensi).

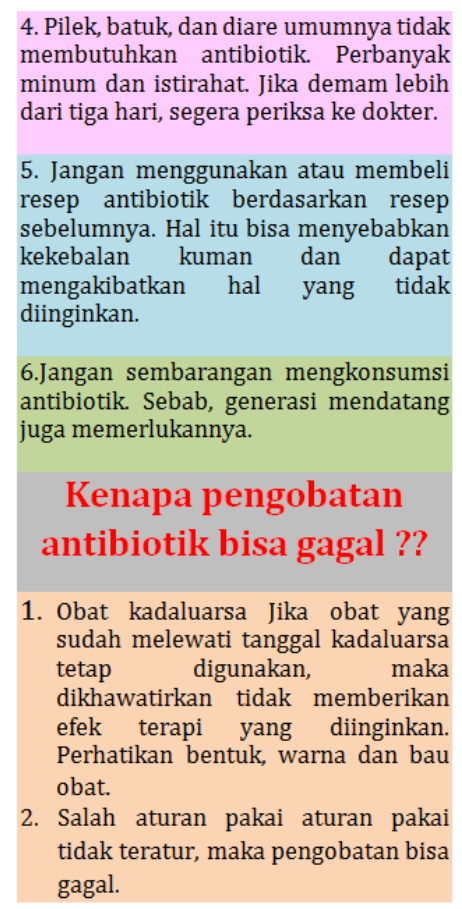
membutuhkan antibiotik. Perbanyak minum dan istirahat. Jika demam lebih dari tiga hari, segera periksa ke dokter.

5. Jangan menggunakan atau membeli resep antibiotik berdasarkan resep sebelumnya. Hal itu bisa menyebabkan kekebalan kuman dan dapat mengakibatkan hal yang tidak diinginkan.

6.Jangan sembarangan mengkonsumsi antibiotik. Sebab, generasi mendatang juga memerlukannya.

Kenapa pengobatan antibiotik bisa gagal ??

1. Obat kadaluarsa Jika obat yang sudah melewati tanggal kadaluarsa tetap digunakan, maka dikhawatirkan tidak memberikan efek terapi yang diinginkan. Perhatikan bentuk, warna dan bau obat.

2. Salah aturan pakai aturan pakai tidak teratur, maka pengobatan bisa gagal.

3. Salah dosis dosisnya ditambah atau dikurangi sehingga tidak efektif atau bisa toksik.

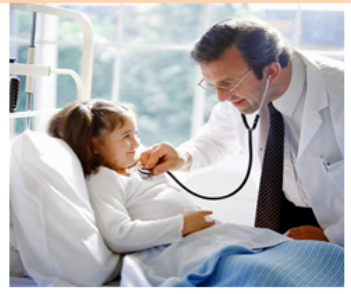

Apa yang sebaiknya
dilakukan sebagai
pasien?
1. Berikan informasi yang lengkap
tentang keluhan sakit kepada dokter
2. Pahami dengan benar aturan pakai
obat yang diberikan
3. Tanyakan tentang obat yang
diberikan kepada dokter atau
apoteker kendang
4. Beritahukan kondisi jika sedang
hamil atau menyusui dan penyakit
lain yang pernah diderita

. Beritahu tentang obat yang sedang dikonsumsi jika ada.

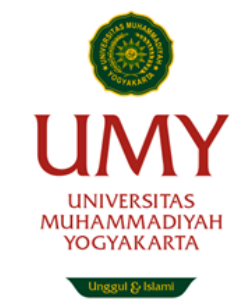

Pengabdian Masyarakat: Pengkaderan kelompok Peduli Penggunaan Antibiotik Rasional
Sebagai Upaya Pencegahan Resistensi Sebagai Upaya Pencegahan Resistensi
Kuman. Inayati - Yoni Astuti - Lilis Suryani

Sosialisasi berjalan dengan baik berdasarkan antusias peserta yang terlibat dalam diskusi dan berinteraksi secara aktif membahas tentang penggunaan antibiotika. 


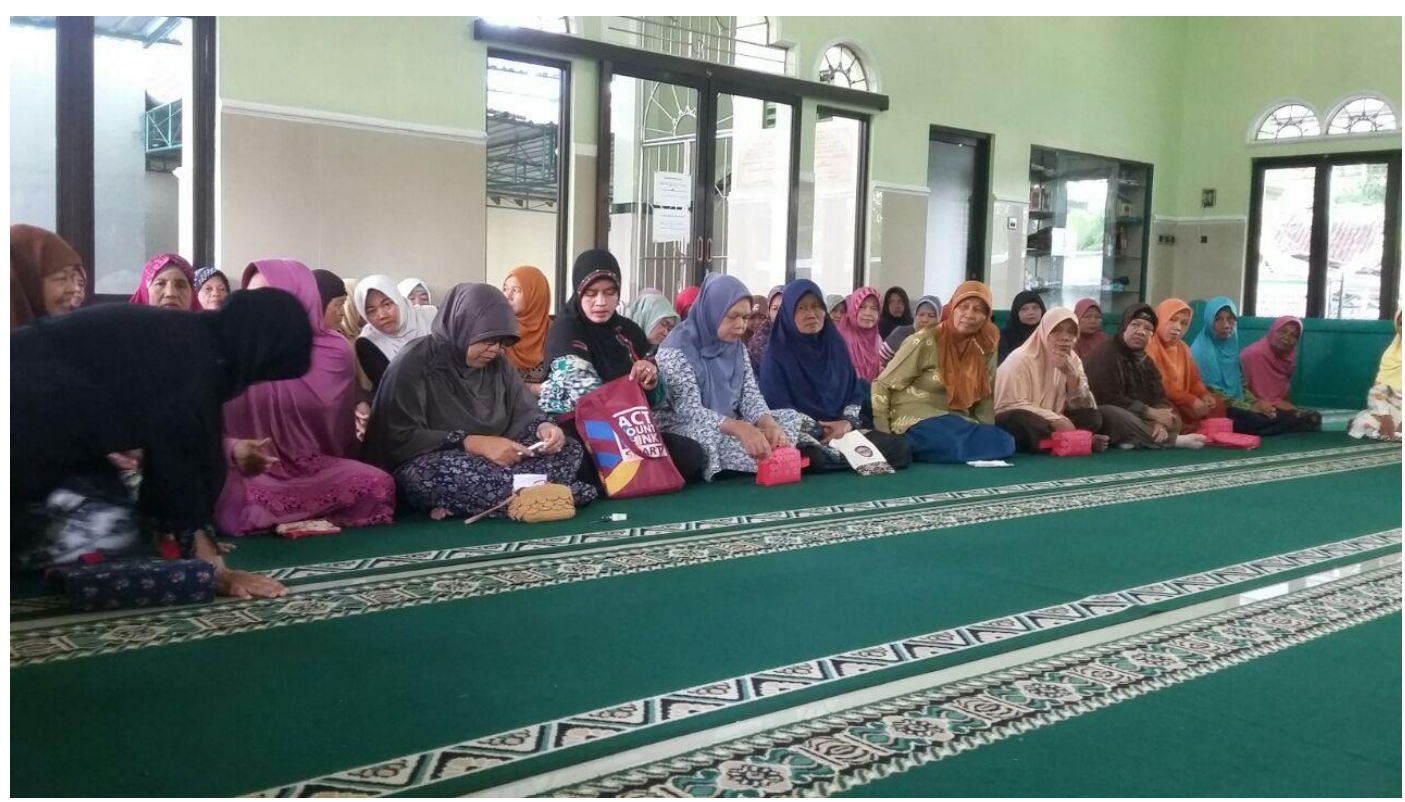

Gambar 1. Peserta sosialisasi Penggunaan Antibiotika

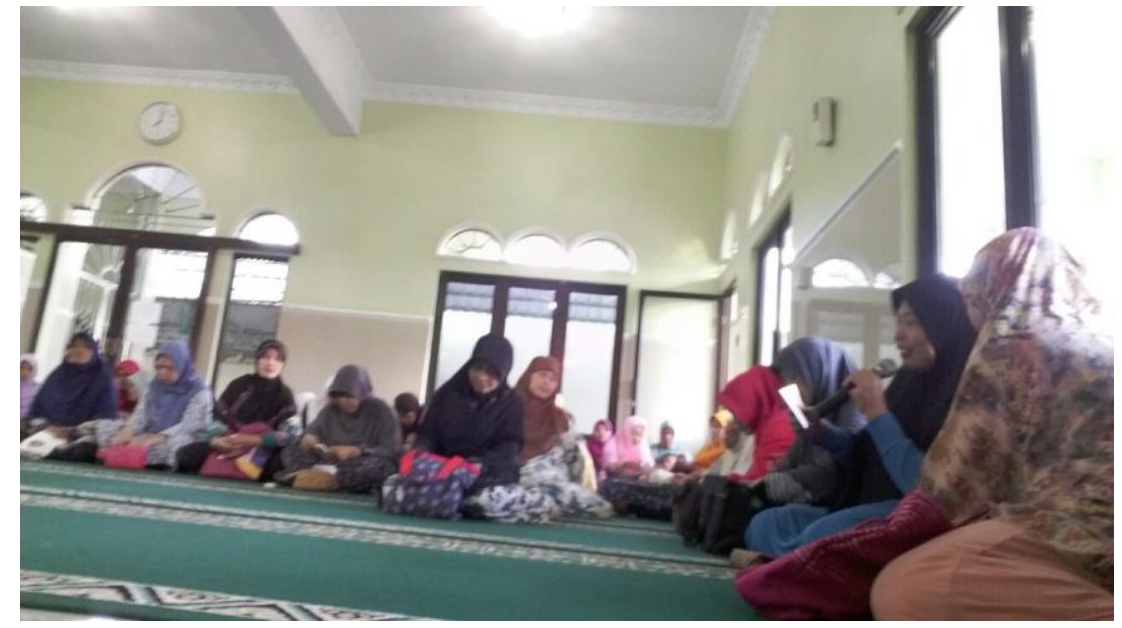

Gambar 2. Peserta sosialisasi Penggunaan Antibiotika

Pelaksanaan Focus Group Discussion "Pengenalan Penggunaan Obat Antibiotika-Upaya Pencegahan Penyebaran Resistensi Antibiotika" pada Jumat, 28 April 2017 di Rumah Ibu Tatik diikuti 32 peserta kader posyandu dan PKK. Terdapat 2 kelompok FGD terdiri 16 peserta dipandu 2 fasilitator dan 2 transkiptor. Kisi-kisi FGD meliputi : Bagaimanakah Pemahaman saudara tentang Obat, Kapankah Antibiotika digunakan? Apakah yang sebaiknya dilakukan apabila terjadi infeksi? Bagaimanakah cara mengkonsumsi Antibiotika? Apakah alasan yang mendasari cara minum tersebut? Bagaimanakah resiko Penggunaan Antibiotika? Apakah yang seharusnya saudara lakukan apabila berobat ke dokter dan mendapat resep Antibiotika pada saat sakit?. Hasil Resume Focus Group Discussion masing-masing kelompok sebagaimana gambar 3 dan gambar 4 


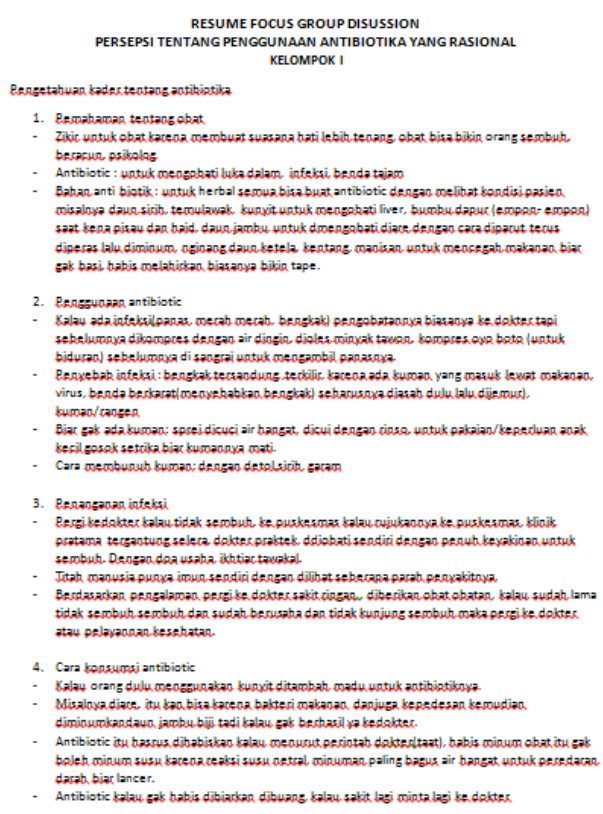

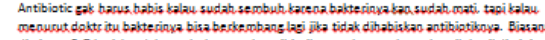

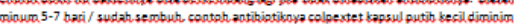
tersan dieccerckan

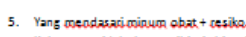

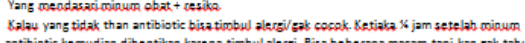

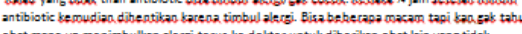

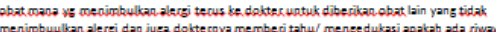

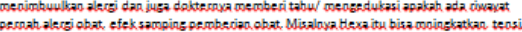
pasien itu bacus bisa oiteroi seadiai

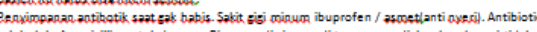

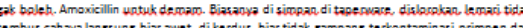
aub daci ianchanan anak anak

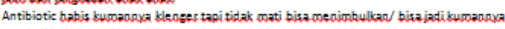

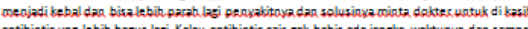

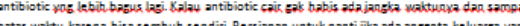

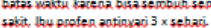

6. Rescreseandahter

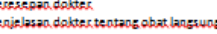

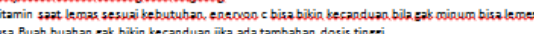

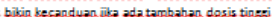

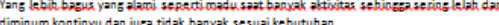

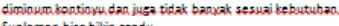

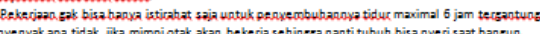

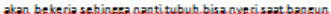

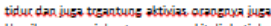

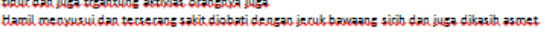

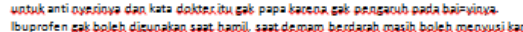

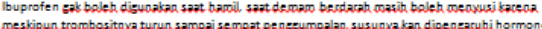

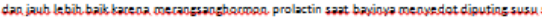

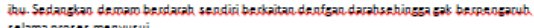

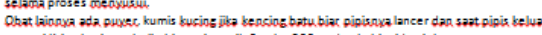

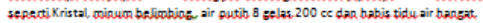
Acraddel paki obati iava (jarpul), obat cina

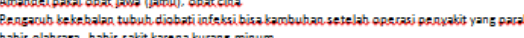

\section{Gambar 3. Hasil Resume Focus Group Discussion Kelompok I}

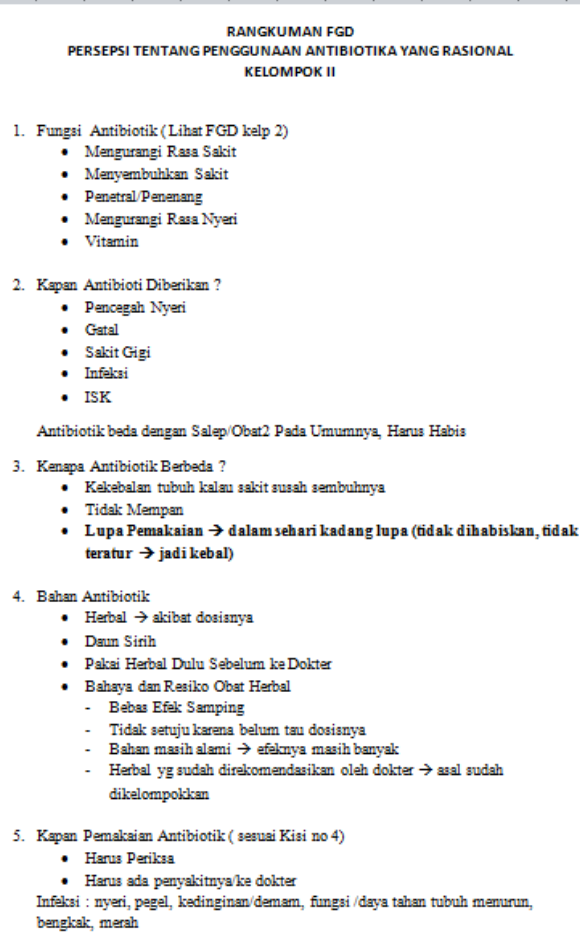

Penanganan jika ada keluarga dengan ciri distas :

- Ke dokter

Diobati Sendiri Paracetamo

Kompres

Puskesmas

Dolter Keluarga

(1) Jika

6. Realssi Jika di kasih Antibiotik oleh dohter : ( sesuai Kisi no 7)

Mengiyalkan

Harus Habis

Jangka Waltu Minumn

Apakah antibiotik ini Bisa Menyembuhkan ?

Dipisah antara antibiotik dan obat lain

Hitungan yg benar apakah pagi, simg malam atsu per $8 \mathrm{jam}$ ?
Antara herbal dan obat kimia $\rightarrow$ katanya boleh setelah salisih $1 \mathrm{jam}$ ?

Pertanyaan? sesuai kisi no 6

Kalsu Sudah minum antibiotilk tapi belum sembuh? $\rightarrow$ bolehkan ads

pemerikasen penurjang ?

Tidak boleh menyimpan antibiotil di numah

Resiko:

Setelah minum gatel 2 /alergi

Jika ada alergi

Dihentikan

Dihantikan

Obat yg menimbulkan alergi dicatat

$\mathrm{Yg}$ disampaikan ke dolter

Hal yg diraskan, awsal muncul, keluhan dill $\rightarrow$ informasi

Sampikan kondisi (hamililmenyusui alergi dll)

\section{Gambar 4. Hasil Resume Focus Group Discussion Kelompok II}

Kegiatan Pelatihan pemantauan dilakukan dengan penjelasan dan pelaksanaan survei tentang Penyediaan dan Penggunaan Obat Antibiotika di Rumah

Tehnik Pelaksanaan Survey sebagai berikut : 
1. Jumlah Peserta Kader: 15 orang, dibagi menjadi 3 kelompok terdiri 5 orang kader /kelompok

2. Survei penyediaan dan penggunaan Obat di rumah dilakukan pada $1 \mathrm{KK}$ oleh seorang kader

3. Hasil survei setiap kader dikumpulkan dalam satu kelompok, dibuat 1 laporan per kelompok

4. Laporan dibuat sesuai format dan akan dipresentasikan masing-masing kelompok pada jadwal pertemuan berikutnya

Hasil Survei masing-masing kelompok ditunjukkan pada tabel

Tabel 1.Hasil Survei tentang Penyediaan dan Penggunaan Obat Antibiotika di Rumah

\begin{tabular}{|c|c|c|c|}
\hline Hasil Survey & Kelompok A & Kelompok B & Kelompok C \\
\hline $\begin{array}{l}\text { Jenis obat- } \\
\text { obatan } \\
\text { ditemukan }\end{array}$ & $\begin{array}{l}\text { Ambroxol, } \\
\text { Amlodipne, } \\
\text { Paracetamol, } \\
\text { Ranitidine, Neurodex, } \\
\text { Cetirizine, } \\
\text { Meloxicam, New } \\
\text { Diatabs, Antasida } \\
\text { syrup, Diapet, } \\
\text { Golongan geliga, } \\
\text { aroma terapi, GPU. } \\
\text { Tidak ditemukan obat } \\
\text { antibiotika dan } \\
\text { kedaluwarsa yan } \\
\text { tersimpan. }\end{array}$ & $\begin{array}{l}\text { Promag, Antimo, } \\
\text { Decolgen, Domperidone, } \\
\text { Becefort, Multivitamin, } \\
\text { diapet, paracetamol, } \\
\text { bethadine, Bioplacenton, } \\
\text { Minyak kayu putih, } \\
\text { Soffel, Permin, Comtusi, } \\
\text { enzymplex, Neuralgin, } \\
\text { Neurosanbe plus, } \\
\text { Lansoprazol, Asam } \\
\text { Mefenamat, Dextral, } \\
\text { Benacol, Myonep, } \\
\text { ibuprofen, ultraflu, } \\
\text { paramex, Glucosamin, } \\
\text { antalgin, tolak angin }\end{array}$ & $\begin{array}{l}\text { Paracetamol, CTM, } \\
\text { antalgin, amlodipine, } \\
\text { Oralit, salbutamol, } \\
\text { ibuprofen, panadol, } \\
\text { ambroxol,hufagesic, } \\
\text { Cetirizin, bufantacid, } \\
\text { Fasidol, Orphen } \\
\text { (CTM), Bodrex, } \\
\text { Bethadine, Aroma } \\
\text { terapi, OBH }\end{array}$ \\
\hline $\begin{array}{l}\text { Umur } \\
\text { Pengguna obat }\end{array}$ & 3 th, 8 th dan 61 tahun & $\begin{array}{l}55 \text { th, } 21 \text { th, } 52 \text { th dan } 45 \\
\text { tahun }\end{array}$ & $\begin{array}{l}67 \text { th, } 70 \text { th, } 69 \text { th dan } \\
36,36,14,6,11,25 \text {, } \\
40,30,67 \text { tahun }\end{array}$ \\
\hline Jumlah KK & 7 & 5 & 6 \\
\hline
\end{tabular}

Pengetahuan dan pemahaman masyarakat dan kader tentang penggunaan antibiotika perlu ditingkatkan yaitu dengan membentuk Kelompok Peduli Penggunaan Antibiotika Rasional Ambarketawang. Anggota Kelompok peduli semua peserta yang terlibat aktif dalam kegiatan Pengabdian Masyarakat ini. Kegiatan Kelompok Peduli menggunakan buku Panduan Kelompok Peduli Penggunaan Antibiotika sebagai pedoman dalam sosialisasi dan penyebaran informasi kepada masyarakat tentang Penggunaan Antibiotika yang rasional.

\section{Simpulan}

Masyarakat memahami obat, antibiotika, dan bahan herbal tetapi belum memahami cara minum antibiotika, pengenalan tanda infeksi dan penanganan infeksi melibatkan aspek kultur dan spiritual. Hasil survei, keluarga menyimpan obat dalam kotak obat. Jenis obat keluarga : obat bagi anggota keluarga usia lanjut, obat bebas terbatas, dan suplemen. Tidak ditemukan antibiotika atau obat kedaluwarsa, terdapat obat dilarang beredar. Kelompok Peduli Penggunaan 
Antibiotika Rasional Ambarketawang melakukan sosialisasi ke masyarakat dengan buku Panduan Kelompok Peduli Penggunaan Antibiotika sebagai pedoman.

\section{Ucapan Terima Kasih}

Terima kasih kepada LP3M UMY atas dukungan dana untuk pelaksanaan Pengabdian Masyarakat Program Ipteks Bagi Masyarakat (Ibm), juga kader Posyandu di Desa Ambarketawang atas partisipasi aktifnya

Daftar Pustaka

Akalin, E. H. 2002. The Evolution of Guidelines In An Era of Cost Containment. Surgical Prophylaxis.J Hosp infect.

AMRIN to PPRA / AMRC Program: a Self Improvement Program in Indonesia[internet]. 2004 [cited 2011 September 22]. Available from http://www.ino.searo.who.int/ 4.

Brad Spellberg, M.D., John G. Bartlett, M.D., and David N. Gilbert, M.D. (2013). The Future of Antibiotics and Resistance. N Engl J Med 2013; 368:299-302January 24, 2013DOI: 10.1056/NEJMp1215093

Chalvy Wowiling, Lily Ranti Goenawi, Gayatri Citraningtyas, 2013. Pengaruh Penyuluhan Penggunaan Antibiotika terhadap Tingkat Pengetahuan Masyarakat di Kota Manado, Pharmacon Jurnal Ilmiah Farmasi-UNSRAT Vol.2 No.03 Agustus 2013 ISSN 2302-2493

Guzman-Blancoetal. 2000; Bacterial Resistance to Antimicrobial Agents in Latin America : The Giant Is Awakening Infectious Disease Clinics of North America Volume 14, Issue 1, 1 March 2000, Pages 67-81

Hadi, U.et al 2008, Audit of Antibiotic Prescribing in Two Governmental Teaching Hospital in Indonesia. Clinical Microbiology and Infection: The Official of The Eur Soc Clin Microb and Inf Dis14(7): 698-707

Peraturan Menteri Kesehatan Republik Indonesia Nomor 2406/Menkes/Per/XII/2011 tentang Pedoman Umum Penggunaan Antibiotika

Peraturan Menteri Kesehatan Republik Indonesia Nomor 8 Tahun 2015 tentang Program Pengendalian Resistensi Antimikroba di Rumah Sakit

Sisti Agustin Manan, 2012. Tingkat Pengetahuan Masyarakat tentang Penggunaan Antibiotik di Desa Daenaa Kecamatan Limboto Barat Tahun 2012 Karya Tulis Ilmiah, Jurusan Farmasi, Fakultas Ilmu - ilmu Kesehatan dan Keolahragaan, Universitas Negeri Gorontalo 